\title{
Amelioration of lipophilic compounds in regards to bioavailability as self-emulsifying drug delivery system (SEDDS)
}

\author{
Pragya Baghel ${ }^{1 *} \mathbb{D}$, Amit Roy ${ }^{1}$, Shekhar Verma ${ }^{2}$, Trilochan Satapathy ${ }^{3}$ and Sanjib Bahadur ${ }^{1}$
}

\begin{abstract}
Background: High lipophilicity and poor aqueous solubility are the endemic problems of new drug molecules. Sixty to seventy percent of these drugs are unable to solubilize completely in aqueous media, or have very low permeability. This hampers their oral absorption and further leads to their poor bioavailability. Various researches are in progress to overcome these limitations. Novel technologies like nano-carrier systems have become popular for improving the solubility of drugs.

Main body: Lipid-based formulations, among nano systems, are taking pace for the enhancement of solubility, oral absorption, and hence the bioavailability of drugs. Among the lipid formulations, self-emulsification systems are gaining popularity by offering various advantages to delivery systems. Self-emulsifying drug delivery systems (SEDDS) are isotropic blends of oil and surfactant/co-surfactants. These ingredients upon gentle agitation in aqueous media results in the formation of o/w emulsion. In spite of many works published in SEDDS, the major concerns of this article are to discuss the various approaches to formulate a good lipid-based carrier system for poorly aqueous soluble drugs, role of various polymers, and their categories used in the formulation along-with the modern technologies used for enhancing the stability of liquid SEDDS. This review majorly focuses upon the problems related to the poor aqueous solubility of the newer lipid molecules and the solutions to overcome their solubility and in addition bioavailability.

Conclusion: As per the researches done in formulation and optimization of SEDDS for the enhancement of bioavailability of lipophilic molecules, it can be stated that the aqueous solubility as well as bioavailability can be increased by many folds compared to their marketed or other oral formulations.
\end{abstract}

Keywords: Dispersion system, Lipophilicity, Self-emulsification, Nano-carrier, Bioavailability

\section{Background}

The medications are commonly administered orally; however, around $40 \%$ of new drug competitors have poor-water solvency and the oral delivery of such medications is troublesome in view of their low bioavailability, high intra- and inter-subject fluctuation, and an absence of dose proportionality $[1,2]$. Low aqueous solvency is the significant issue experienced with

\footnotetext{
* Correspondence: pragyabaghel88@gmail.com

${ }^{1}$ Columbia Institute of Pharmacy, Vil.-Tekari, Near Vidhan Sabha, Raipur, Chhattisgarh, India

Full list of author information is available at the end of the article
}

development of new chemical compounds [3-5]. Restricted aqueous dissolvability and high lipophilicity confine the remedial result for all medications [1]. It is advisable to broaden the therapeutic efficacy of medications by expanding the bioavailability of the medication and additionally by reducing interpatient changeability in plasma level concentration [4-6]. The most important factor for drugs administered orally is their solubility [2]. The desired concentration of any drug to achieve its pharmacological response is based on this factor majorly and thus it is most challenging for formulation scientists to maintain the pharmacological range of such poorly

\section{Springer Open}

(๑) The Author(s). 2020 Open Access This article is licensed under a Creative Commons Attribution 4.0 International License, which permits use, sharing, adaptation, distribution and reproduction in any medium or format, as long as you give appropriate credit to the original author(s) and the source, provide a link to the Creative Commons licence, and indicate if changes were made. The images or other third party material in this article are included in the article's Creative Commons licence, unless indicated otherwise in a credit line to the material. If material is not included in the article's Creative Commons licence and your intended use is not permitted by statutory regulation or exceeds the permitted use, you will need to obtain permission directly from the copyright holder. To view a copy of this licence, visit http://creativecommons.org/licenses/by/4.0/. 
aqueous soluble drugs [1]. Poor aqueous solubility and low dissolution rate are the major cause of inadequate oral bioavailability of lipophilic drugs $[4,5,7]$.

To overcome these issues, various strategies are opted including the use of surfactants, lipids, permeation enhancers, micronization, salt formation, cyclodextrin complexation, nanoparticles, and solid dispersions $[8,9]$. Various factors influence the oral bioavailability, such as aqueous solubility, drug permeability, dissolution rate, first-pass metabolism, presystemic metabolism, and susceptibility to efflux mechanisms [10]. Lipid soluble drugs require higher doses to reach therapeutic plasma concentrations following oral administration [11]. An enhancement in the solubility and dissolution rate can enhance the oral bioavailability of such compounds, which in addition improves the healing efficacy and patient compliance [12]. This can be beneficial in lowering of frequent dosing of the drugs, required to obtain the identical/extended degree of bioavailability determined with a traditional formula. This would enhance predictability of the remedy and increase uniformity of treatment in patient population [8]. Liposomes, solid lipid nanoparticles (SLN), nanostructured lipid carriers (NLC), emulsions, and nanoemulsions, are some lipidbased formulations that have been used to improve the performance of poorly water-soluble bioactive compounds [13]. By increasing the solubilization and stability, of the lipid-based drugs, plus providing a sustained, targeted and triggered delivery system they enhance the aqueous solubility [14].

Lipinski's rule of five has gained a valued importance as qualitative predictive model for the estimation of absorption of poorly absorbed drug molecules. In his finding, it was stated that "the rule of 5" predicts that poor absorption or permeation is more probable when there are more than $5 \mathrm{H}$-bond donors, $10 \mathrm{H}$-bond acceptors, the molecular weight is greater than 500 , and the calculated $\log \mathrm{P}$ is greater than 5 . This rule is effective for the drugs that are not substrates for active transporters and efflux mechanisms [15].

\section{Main text}

It is possible to enhance the oral bioavailability and reduce the probable side effects of an active pharmaceutical ingredient with lipid-based carrier systems. Lipidbased carriers are less toxic compared to other delivery systems, as they are biocompatible and biodegradable [16].

\section{Solubility}

Enhancement of solubility thereby oral bioavailability of such drug molecule remains one of the most difficult aspects of the drug development process especially for oral-drug delivery system [17]. Various approaches are stated in literatures and are available for the enhancement of solubility of poorly aqueous soluble drugs, especially when administered orally. These approaches are opted based on certain aspects, such as properties of drug under consideration, nature of excipients to be selected, and nature of intended dosage form. In addition, modification of crystal habit, reduction of particle size, solid dispersions, solid solutions, salt formation, and miscellaneous methods, including supercritical fluid process and use of surfactant, solubilizers, cosolvency, hydrotrophy, and novel excipients as adjuvant to increase solubility are considered [18]. In practice, the occurrence of spontaneous emulsification is difficult to establish because when mechanical agitation is absent gravitational force provides a small quantity of energy for emulsification. The ratio and overall concentration of oils and surfactants in each formulation will determine the rate and extent of the absorption of any drug [19]. To enhance the rate of absorption, digestibility of oil and partition of the drug between the two phases should be optimized. The principal concept of lipid-based drug delivery system is to bring the drug in its dissolved state, by the formation of its colloidal dispersion in the gastrointestinal tract. This dispersion helps to enhance the solubility and absorption of lipophilic drugs in aqueous system. Various forms of lipid-based delivery systems are present, namely solutions, suspensions, emulsions, microemulsions, SEDDS, or dry emulsions [20].

\section{Theory of Pouton}

In the year 2000, Pouton introduced one useful lipid formulation classification system (LFCS). LFCS was recreated in the year 2006 by Pouton himself. As per the LFCS, SEDDS (type II) is an isotropic mixture of oil or mixture of oils and surfactant/s and on exposure to the gastric media; it gets emulsified [21]. Therefore, it can be said that the self-emulsifying systems improves the absorption and distribution of drug by avoiding the slow dissolution and gastric irritation, leading to improved bioavailability of lipid-soluble drugs. Ability to dissolve the poorly aqueous drugs in suitable solvents, thereby enhancing their absorption and bioavailability, is the major reason behind the growing demand of lipidic excipients [22].

\section{Lipid-based drug delivery system classification by Pouton} Pouton classified the lipid-based delivery system for poor aqueous soluble drugs into four categories, as described in the table below (Table 1).

Various in-vivo properties of lipid-based delivery systems associated with their bioavailability enhancing property include the following: 
Table 1 Classification of LBDDS by Pouton

\begin{tabular}{llllll}
\hline Category & OIL (lipophilic) & Surfactant (lipophilic) & Surfactant (hydrophilic) & Co-solvents & Formulations \\
\hline Category I & $100 \%$ & $0 \%$ & $0 \%$ & $0 \%$ & Simple oily solutions \\
Category II & $40-80 \%$ & $20-60 \%$ & $0 \%$ & $0 \%$ & SEDDS \\
Category III & $0 \%$ & $20-40 \%$ & $20-40 \%$ & $20-50 \%$ & SMEDDS \\
Category IV & $0 \%$ & $0-20 \%$ & $20-80 \%$ & $0-80 \%$ & Colloidal micellar dispersions
\end{tabular}

SEDDS self-emulsifying drug delivery systems, SMEDDS self-micro-emulsifying drug delivery systems [23]

1. Prevention of drug precipitation and recrystallization by the formation of fine dispersion and micellar suspension

2. Improved drug absorption by implying certain changes in GIT by the lipid compounds and its metabolites

3. This system has the ability to inhibit the efflux system, which fluctuates the distribution of drug. Controlled efflux system controls the drug circulation in the cellular system.

4. Helps reduce the first-pass drug metabolism by the mechanism of drug uptake directly into the lymphatic transport [24].

Digestion and absorption are the two complex mechanisms, which are yet to be understood well by the scientists. However, lipid excipients provide a safe and effective way of formulating a lipophilic drug with enhanced solubility and bioavailability. In addition to the solubility and bioavailability, this system introduces various improved chemical and mechanical technologies to deal with such problems $[1,4,5]$.

\section{Self-emulsifying drug delivery systems}

As per the known definitions, SEDDS are isotropic mixtures of natural/synthetic oils, solid/ liquid surfactants, and/or one or more hydrophilic solvents and cosolvents/surfactants [25]. Again, as stated earlier, with a mild agitation they dilute the drug in the system (aqueous media), such as GI fluids, and forms fine oil-inwater $(\mathrm{o} / \mathrm{w})$ emulsions $(0.1-100 \mu \mathrm{m})$ or microemulsions $(10-300 \mathrm{~nm})$, spreading readily into the GIT where agitation is provided by the movement of the stomach and intestinal fluid forming a self-emulsified system [26].

Figure 1 represents an illustrative diagram explaining the mechanism of self-emulsification.

SEDDS are modified further as self-micro emulsifying drug delivery systems (SMEDDS) or self-nanoemulsifying drug delivery systems (SNEDDS) drug delivery systems, classified as type IIIa or IIIb, respectively [27]. This modified form additionally contains one or more co-surfactant or co-solvents (hydrophilic) [28]. By the application of ternary phase diagram, and modifying the rations of oil/ surfactant, SEDDS can be prepared experimentally, using the "trial-error" method [29].

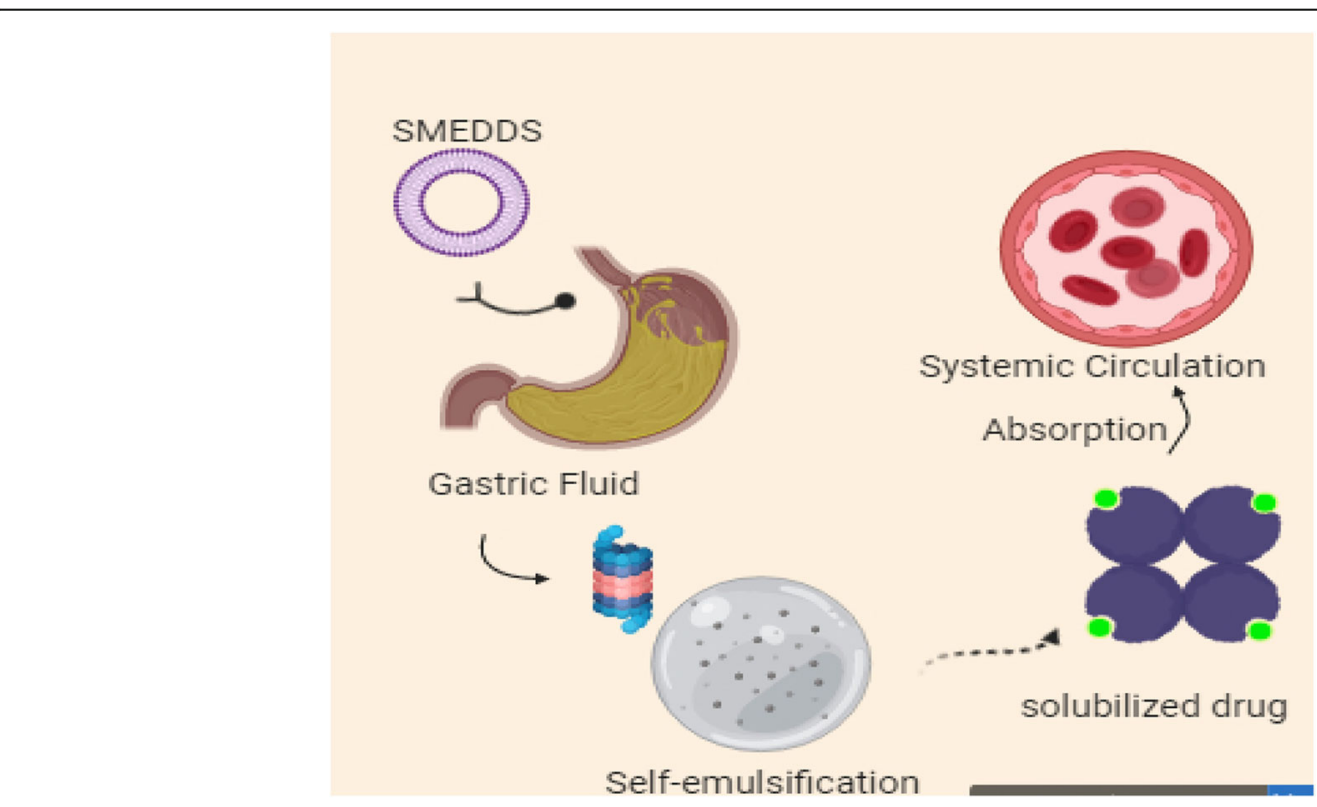

Fig. 1 Mechanism of self-emulsification 


\section{Advantages}

Potential advantages of these systems (SEDDS) include the following:

1. Dose reduction by ability to improve the solubility

2. More steady chronological profiles of drug absorption

3. Specific absorption from targeted area

4. Drug protection from the unstable GIT surroundings

5. Control of delivery profiles

6. Reduction in variable drug action

7. Protection of susceptible drug substances

8. Enhanced drug potential

9. Available in both liquid and solid dosage forms

10. No/less, influence of lipid digestion on SEDDS

11. Drug dose can be reduced by these formulations.

12. Easy manufacturing and scaling up technique is used.

13. This formulation provides quick onset of action [29, 30].

\section{Suitable drug candidates for SEDDS}

Although SEDDS is suitable for all the four categories of BCS classification system, but the candidates that are required to be formulated as SEDDS fall under BCS class II and IV categories [31].

\section{Application of SEDDS in drug solubility and dissolution}

1. SEDDS aids in the incorporation of active pharmaceutical ingredients (API's) in a lipid vehicle imparting improved drug dissolution in an aqueous medium.

2. Improved drug dissolution affects the drug release and GI-absorption.

3. In addition, drug can easily penetrate into the surfactant interfacial layer, which enhances its penetration through membrane barriers and its efficacy [32].

\section{Applications of self-nanoemulsifying drug delivery system} and its novel approaches

1. Various novel advancements in SNEDDS include solid SNEDDS, super saturated SNEDDS, selfdouble emulsions $(\mathrm{w} / \mathrm{o} / \mathrm{w})$, controlled release SNEDDS, SNEDDS for overcoming mucus gel barrier, delivery of biomolecules, and even drug targeting.

2. Super saturated SNEDDS include hydrophobic precipitation inhibitors that control drug precipitation, during storage, hence improving its stability.
3. Solidification of liquid SNEDDS (L-SNEDDS) inhibits the interaction of drug and excipients, interaction of liquid dosage with the capsule shell, etc.

4. Biomolecules with low bioavailability can be designed easily using SNEDDS, as they provide small droplet size and maximum surface area for the better penetration of molecules.

5. Other advancements like targeted SNEDDS, selfdouble SNEDDS have also gained popularity in increasing the solubility, bioavailability, and stability of molecules [33].

\section{Dosage forms of SEDDS}

Various dosage forms, such as capsules, sustained release, and controlled release tablets/pellets, dispersion systems can be easily formulated using self-emulsified dosage design. SEDDS is also suitable for other routes other than oral, like topical, ocular, pulmonary, and parenteral route [34].

\section{Composition of self-emulsifying drug delivery systems}

Self-emulsification process depends upon the following:

1. Nature and ratio of oils and surfactants

2. Concentration of surfactant

3. Temperature and time of self-emulsification [35]

\section{Excipients used in the formulation of SEDDS \\ Oils}

The most important and basic ingredient of SEDDS are oils, as they have the ability to dissolve lipid molecules and improve their solubility [36]. Depending upon the nature of triglycerides, drug transportation of the lipid drug is increased, via the lymphatic system. In addition, GIT absorption of the drug is also increased [37]. Generally, long and medium-chain triglycerides (LCT and $\mathrm{MCT}$ ) are preferred for the formulation of SEDDS. The LCT and MCT are used with different degrees of saturation [38]. Dietary lipids undergo lipolysis, and are converted to monoglycerides and free fatty acids. Shortchain triglycerides (SCT) and MCT get absorbed quickly and reach the systemic circulation as soluble fatty acids. Whereas a different absorption is found for the LCT, as they get absorbed they esterify and forms chylomicrons. Triglycerides, apoproteins, cholesterol, and cholesterol ester comprises the chylomicrons. They are absorbed through the lymphatic uptake. This serves as a vehicle system here, for various lipophilic molecules, bypassing the liver [39].

List of oils used in the formulation of SEDDS/ SMEDDS/SNEDDS:

1. Glyceryl monolinoleate 
2. Maisine $35-1$

3. Neobee M5

4. Miglyol 840

5. Labrafac lipophile WL139

6. Kolliphore RH 40

7. Oleic acid

8. Captex 200

9. Captex $355 \mathrm{EP} / \mathrm{NF}$

10. Other vegetable ad edible oils (castor, sesame, olive, coconut, etc.)

\section{Surfactants}

Surfactants are having amphiphilic character. They help in the solubilization of lipophilic drug compounds. In the gastro intestinal lumen, this prevents precipitation of drug [40]. Hence, drug sustains in the GIL for a definitely longer time [32]. For the formulation of SEDDS, various compounds having surfactant properties can be used, but those having oral acceptance should be chosen [41]. Surfactants are of four types, namely cationic (quaternary ammonium halide), anionic (potassium laureate, sodium lauryl sulfate), ampholytic (sulfobetaines), and non-ionic surfactants [sorbitan esters (spans), polysorbates (tweens)] [42]. Among all the surfactants, the most preferable ones are the non-ionic surfactants, having relatively high hydrophilic-lipophilic balance (HLB) [43]. Optimum concentration of surfactants, for the formulation of a stable SEDDS is 30-60\% [35, 44-46].

Surfactants are grouped as follows:

- Anionic surfactants

- Cationic surfactant

- Ampholytic surfactants

- Non-ionic surfactants

(a) Anionic surfactants-in this class, the hydrophilic group carries a negative charge, for example, carboxyl (RCOO-), sulfonate (RSO3-), or sulfate (ROSO3-).

(b) Cationic surfactants-in this class, the hydrophilic group carries a positive charge.

(c) Ampholytic surfactants-(also called zwitterionic surfactants) contain both a negative and a positive charge.

(d) Non-ionic surfactants-in this class, the hydrophilic group carries no charge but imparts water solubility from its polar groups such as hydroxyl or polyoxyethylene (Tweens) [44].

\section{Biosurfactants}

Surfactants may alter the therapeutic efficacy of the drug molecule, as its concentration may vary and as a result may hamper the availability of the rug at the absorption site. It may also produce some toxicity at various concentrations. This can be overcome by the use of biosurfactants in place of normal surfactants. Biosurfactants increase the safety and decrease toxicity associated with the gastric irritation caused by the surfactants [47].

\section{Co-solvents}

Organic solvents are one of the best options to be used as co-solvents for SEDDS, such as ethanol, propylene glycol, and polyethylene glycol, this aid in the increased solubility of lipid drugs [5]. Higher concentrations of surfactant are required for the optimum formulation of SEDDS, but this higher concentration may lead to the drug precipitation [48]. Therefore, co-solvents are added to lower the surfactant concentration and maintain the uniformity of the formulation $[4,49]$.

\section{Co-surfactant}

In addition to co-surfactant, the concentration of surfactants can be decreased, as it increases the loading capacity of the active pharmaceutical compound. Cosurfactants increase the interfacial fluidity and hence reduce the chances of variability and local irritation caused by surfactants also enhancing the process of dispersion in the medium [50]. Ethanol, propylene glycol, and other newer co-surfactants such as transcutol P and Glycofurol are a few of common excipients used as cosurfactants [51].

Some examples of co-surfactants and co-solvents:

1. Mixture of glycerol an ethanol

2. Transcutol

3. Capmul MCM

4. Glycerol

5. Polyethylene glycol

6. PEG 400

7. Glycofurol

Newer components of formulation in SEDDS and SMEDDS SEDDS and SMEDDS have gained popularity among other nanoparticle dosage forms in many ways. Further modifications on SEDDS and SMEDDS are done by including some more new components that can enhance drug absorption. However, the selection of these components largely depends on the proper ratio of the mixture of oil and surfactant along with the co-surfactant and co-solvents. Still, some modifications have been made for the enhancement and stability of such formulations. These include the inclusion of adsorbents like silica gel and neusilin to solidify the liquid formulation. Grafted polymers are being use as modifiers such as, aeroperl and soluplus. Along with the components, various techniques are being adopted for improving the stability and efficacy of these dosage forms [52]. 
Role of polymers in SEDDS and SMEDDS formulation The below Table 2 summarizes a few of polymers along with few excipients which plays different roles in the design and optimization of SEDDS and SMEDDS.

\section{Importance of emulsion droplet size on drug absorption}

Globule size of the particles in microemulsion is the factor affecting the bioavailability at different levels [55]. It has been stated that dispersion at nano-scale affects the rate of drug absorption, but it cannot be said exactly that lower droplet size will enhance the bioavailability of the drugs [56]. Yap and Yuen stated that bioavailability of tocotrienol SEDDS from two microemulsions, one of which is very prone to lipolysis while another with minor emulsion globule range, showed similar results, regardless of the droplet size [57].

\section{Challenges of using S-SMEDS in food and pharmaceutical industries}

In order to lower the surface tension between the two phases, higher concentrations of surfactant and cosurfactant are required, this may lead to the increase in toxicity [58]. Although the cytotoxicity of surfactants, which are, generally used in food and pharmaceutical systems, has been widely studied, little is known about the toxicity of surfactants in microemulsions and especially in solid self-emulsifying drug delivery systems (SSMEDDS). Some studies reported that the toxicity of a surfactant would change in these systems [59]. For example, Warisnoicharoen et al. established a fact that using Brij97 (polyoxyethylene-10-oleyl ether) alone or in a combined form with low molecular weight (LMW) oils was toxic over a range above its critical aggregation concentration [60]. However, a combination of Brij97 with high molecular weight oils (e.g., Miglyol 812 and soybean oil) was observed to be toxic only at levels higher than the critical aggregation concentration [5, 61]. The formation of a distinct oil core in the aggregates, which resulted in lowering the ability of the system to solubilize the cell membrane components, was suggested to be the reason of reducing the toxicity of the high molecular weight oil microemulsions. Some researchers and scientists found that the cell toxicity of single components of vitamin E microemulsions (e.g., El-35 and ethyl butyrate) was higher than that of the microemulsions [62]. Some researchers and scientists evaluated the cytotoxicity of $\beta$-carotene microemulsions prepared from Tween 80 and medium-chain triglycerides (Capmul MCM) [46]. An increase in toxicity was observed at concentration higher than $0.0313 \%$ when Tween 80 interacted with the cell culture monolayer [63]. According to the recent research, it was found that microemulsions and SEDDS formulation of atrovastatin was cytotoxic, with the use of isopropyl myristate, a combination of 2 biocompatible surfactants: lecithin/D- $\alpha$-tocopheryl polyethylene glycol succinate (TPGS) and ethanol as cosurfactant [64]. The S-SMEDDS formulations prepared with lecithin-20 had highest in vitro cytotoxicity and lowest IC50 than those prepared with lecithin-100 [65]

\section{Enhancement of stability through SEDDS and SMEDDS}

With the formulation of SEDDS and SMEDDS, researchers have found that the formulation design is optimum for the lipophilic drugs. Enhancement of oral solubility and bioavailability is proven parameters for these systems. However, there are some drawbacks like physical stability and pharmacokinetics of the formulation system, which has to be overcome. Certain modifications have been made regarding the issues raised. One of which is the formation of the liquid preconcentrate to its solid form. Liquid solid compacts are one such modifications, these are a mixture of liquid preconcentrate

Table 2 Role of polymers

\begin{tabular}{|c|c|c|c|}
\hline S. no & Polymer used & Role of polymer & Reference \\
\hline 1. & $\begin{array}{l}\text { Polyvinyl caprolactam-polyvinyl acetatepolyethylene glycol graft } \\
\text { copolymer (Soluplus }{ }^{\oplus} \text { ) and Aeroperl }{ }^{\oplus} \\
300 \text { Pharma }\end{array}$ & Formation of spray-dried solid dispersion & [52] \\
\hline 2. & Stearic acid phosphotyrosine & Zeta potential modifier in SEDDS & [53] \\
\hline 3. & Polyvinylpyrrolidone (PVP) VA64 and sodiumdodecyl sulfate (SDS) & Combined stabilizers & [16] \\
\hline 4. & $\begin{array}{l}\text { Soluplus }{ }^{\circledast} \text { mixed with D-a-tocopheryl polyethylene } \\
\text { glycol-1000-succinate (TPGS) }\end{array}$ & $\begin{array}{l}\text { Formation of micelles for improved stability } \\
\text { and bioavailability }\end{array}$ & [14] \\
\hline 5. & Soluplus & Supersaturation stabilizer & [27] \\
\hline 6. & Neusilin US2 ${ }^{\circledast}$ - (excipient) & Solidification & [43] \\
\hline 7. & Precipitated papain & Mucus permeation enhancer & [42] \\
\hline 8. & Fujicalin (dibasic calcium phosphate) - (excipient) & Porous carrier as adsorbent & [54] \\
\hline
\end{tabular}


Table 3 List of drugs formulated as solid/liquid self-micro emulsified drug delivery systems (SMEDDS)

\begin{tabular}{|c|c|c|c|c|c|}
\hline Drug & Oils & Surfactant/co-surfactant & Formualtion type & Therapeutic outcome & Ref. \\
\hline Silybin & Labrafac & Cremophore RH40/transcutol & $\begin{array}{l}\text { Supersaturatable self- } \\
\text { emulsifying drug delivery } \\
\text { system (S-SEDDS) }\end{array}$ & Enhanced oral bioavailability & {$[6]$} \\
\hline Fenofibrate & $\begin{array}{l}\text { Medium-chain triglyceride } \\
\text { oil (Myritol 318), }\end{array}$ & $\begin{array}{l}\text { TPGS (D-a-tocopheryl } \\
\text { polyethylene glycol } 1000 \\
\text { succinate) and polysorbate } \\
\text { (Tween } 80 \text { or Tween 20) }\end{array}$ & $\begin{array}{l}\text { Self-microemulsifying } \\
\text { drug delivery system } \\
\text { (SMEDDS) }\end{array}$ & Increased oral bioavailability & [13] \\
\hline $\begin{array}{l}\text { Rosuvastatin } \\
\text { calcium }\end{array}$ & Capmul MCM & $\begin{array}{l}\text { Cremophore ELP/Propylene } \\
\text { Glycol }\end{array}$ & $\begin{array}{l}\text { Solid self-emulsifying } \\
\text { drug delivery system }\end{array}$ & Improved bioavailability & [19] \\
\hline Celastrol & $\begin{array}{l}\text { Corn oil, soybean oil, ethyl } \\
\text { oleate, GTCC, IPM, castor } \\
\text { oil, masine-1, olive oil, IPP }\end{array}$ & $\begin{array}{l}\text { Labrafil M1944, Labrasol, } \\
\text { OP-10/ Transcutol P }\end{array}$ & $\begin{array}{l}\text { Solid self- } \\
\text { microemulsifying } \\
\text { dispersible tablets }\end{array}$ & Increased bioavailability & [26] \\
\hline $\begin{array}{l}\text { Alginate and } \\
\text { curcuin }\end{array}$ & $\begin{array}{l}\text { Cremophor EL, Larafac PG, } \\
\text { Capryol } 90\end{array}$ & $\begin{array}{l}\text { Labrasol, Sodium CMC } \\
\text { (absorbent), Aerosil } 200\end{array}$ & $\begin{array}{l}\text { Curcumin loaded solid } \\
\text { SMEDDS designed by } \\
\text { freeze-drying technique }\end{array}$ & $\begin{array}{l}\text { Enhance the release profile } \\
\text { of drug }\end{array}$ & [28] \\
\hline Dutasteride & Capryol 90 & Cremophore EL/transcutol HP & $\begin{array}{l}\text { Gelatin micropatrticles of } \\
\text { a self-emulsified system }\end{array}$ & $\begin{array}{l}\text { Enhanced oral bioavailability } \\
\text { of dutasteride }\end{array}$ & [34] \\
\hline Dutasteride & Capryol 90 & Cremophore EL/ Transcutol HP & $\begin{array}{l}\text { Soluplus-based } \\
\text { supersaturable self- } \\
\text { emulsifying drug } \\
\text { delivery system }\end{array}$ & $\begin{array}{l}\text { Improved oral absorption of } \\
\text { dutasteride }\end{array}$ & [35] \\
\hline Carbamazepine & $\begin{array}{l}\text { Caprylic/ Capric } \\
\text { triglycerides }\end{array}$ & $\begin{array}{l}\text { Polysorbate 80/cremophore-RH } \\
40\end{array}$ & $\begin{array}{l}\text { Solid self- } \\
\text { microemulsifying } \\
\text { drug delivery systems }\end{array}$ & $\begin{array}{l}\text { Improved drug release and } \\
\text { increase bioavailability }\end{array}$ & [45] \\
\hline $\begin{array}{l}\text { ELQ - } 331 \\
\text { (antimalarial } \\
\text { prodrug) }\end{array}$ & $\begin{array}{l}\text { Tween-20, Span }{ }^{\circledast} 85, \text { PEG } \\
400 \text { and sodium lauryl } \\
\text { sulfate }\end{array}$ & $\begin{array}{l}\text { Tween-20, Span }{ }^{\circledast} 85, \text { PEG } 400 \\
\text { and sodium lauryl sulfate }\end{array}$ & $\begin{array}{l}\text { Preparation of spray } \\
\text { dried dispersions and its } \\
\text { comparison }\end{array}$ & $\begin{array}{l}\text { Described the effect on the } \\
\text { solubility and bioavailability } \\
\text { of prodrug }\end{array}$ & [52] \\
\hline Glyburide & $\begin{array}{l}\text { Capryol 90, Lauroglycol 90, } \\
\text { Labrafac Hydro WL 1219, } \\
\text { polyglyceryl-3 dioleate }\end{array}$ & $\begin{array}{l}\text { Labrasol, Tween 20/glycofurol, } \\
\text { transcutol, PEG } 400\end{array}$ & $\begin{array}{l}\text { fast-dissolving solid self- } \\
\text { microemulsifying tablets }\end{array}$ & $\begin{array}{l}\text { Improve dissolution and } \\
\text { technological properties }\end{array}$ & [58] \\
\hline Ritonavir & Imwitor 988 & $\begin{array}{l}\text { Cremophore EL and cremophore } \\
\text { RH } 40 \text { (1:1)/capmul GMS K-50 }\end{array}$ & $\begin{array}{l}\text { Solid self- } \\
\text { microemulsifying drug } \\
\text { delivery system }\end{array}$ & $\begin{array}{l}\text { Enhance dissolution and oral } \\
\text { bioavailability of drug }\end{array}$ & [67] \\
\hline Simvastatin & Capryol 90 & Kolliphor EL/transcutol P & $\begin{array}{l}\text { Self-emulsifying drug } \\
\text { delivery system }\end{array}$ & Improved drug release & [68] \\
\hline Carbamazepine & Mygliol 812 & Cremophor EL/macrogol 400 & $\begin{array}{l}\text { Solid self- } \\
\text { microemulsifying drug } \\
\text { delivery systems (S- } \\
\text { SMEDDS) }\end{array}$ & $\begin{array}{l}\text { Increase in dissolution rate } \\
\text { compared to pure } \\
\text { Carbamazepine }\end{array}$ & [69] \\
\hline Naproxen & Miglyol 812 & Gelucire 44/14 & $\begin{array}{l}\text { Tablets and mini-tablets } \\
\text { of spray dried SMEDDS }\end{array}$ & $\begin{array}{l}\text { Lowered dissolution profile } \\
\text { of naproxen from tablets } \\
\text { and minitablets }\end{array}$ & [70] \\
\hline Atrovastatin & Oleic acid and capryol 90 & 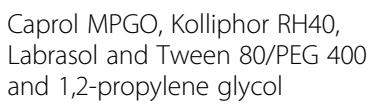 & $\begin{array}{l}\text { Liquid and solid Self- } \\
\text { Emulsifying Drug Delivery } \\
\text { Systems }\end{array}$ & $\begin{array}{l}\text { better solubilization properties } \\
\text { exhibited by solid formulation }\end{array}$ & [71] \\
\hline Atorvastatin & Isopropyl myristate & $\begin{array}{l}\text { lecithin/D-a-tocopheryl } \\
\text { polyethylene glycol } \\
\text { succinate/ethanol }\end{array}$ & $\begin{array}{l}\text { Spray-dried self- } \\
\text { microemulsifying drug } \\
\text { delivery systems }\end{array}$ & $\begin{array}{l}\text { Enhanced the cytotoxic } \\
\text { activity on lung cancer cells }\end{array}$ & [72] \\
\hline $\begin{array}{l}\text { Paprika Oleoresin } \\
\text { (carotenoid) }\end{array}$ & Limonene & Tween 80/ethanol & $\begin{array}{l}\text { Solid self- } \\
\text { microemulsifying system }\end{array}$ & $\begin{array}{l}\text { Enhanced bioavailability and } \\
\text { pigmentation }\end{array}$ & [73] \\
\hline Naproxen & Miglyol 812 & Gelucire 44/14/glycerin & Solid SMEDDS & $\begin{array}{l}\text { Preserved the self- } \\
\text { microemulsifying properties } \\
\text { of liquid SMEDDS \& exhibited } \\
\text { dissolution profiles similar to } \\
\text { liquid SMEDDS }\end{array}$ & [74] \\
\hline Atorvastatin & $\begin{array}{l}\text { Coconut oil and } \\
\text { Isopropyl myristate }\end{array}$ & Tween 80/PEG 400 and glycerin & $\begin{array}{l}\text { Solid self-micro } \\
\text { emulsification system }\end{array}$ & Improve bioavailability & [75] \\
\hline
\end{tabular}


Table 3 List of drugs formulated as solid/liquid self-micro emulsified drug delivery systems (SMEDDS) (Continued)

\begin{tabular}{|c|c|c|c|c|c|}
\hline Drug & Oils & Surfactant/co-surfactant & Formualtion type & Therapeutic outcome & Ref. \\
\hline Mefanamic Acid & $\begin{array}{l}\text { clove oil, olive oil and rice } \\
\text { bran oil, Imwitor } 742\end{array}$ & $\begin{array}{l}\text { Tween 60, cremophore } \\
\text { El/transcutol HP }\end{array}$ & $\begin{array}{l}\text { Self-emulsifying } \\
\text { formulation }\end{array}$ & Enhance solubility & $\overline{[76]}$ \\
\hline Atrovastatin calcium & Capmul $^{\circledR}$ MCM & Tween $^{\oplus}$ 20/tetraglycol & $\begin{array}{l}\text { Solidified self- } \\
\text { microemulsifying drug } \\
\text { delivery system }\end{array}$ & $\begin{array}{l}\text { Improve dissolution and } \\
\text { bioavailability }\end{array}$ & [77] \\
\hline Mebendazole & Labrafil 2125 CS & Tween 20/maisine 35-1 & $\begin{array}{l}\text { Self-microemulsifying } \\
\text { drug delivery System }\end{array}$ & $\begin{array}{l}\text { Improve dissolution and } \\
\text { bioavailability }\end{array}$ & [78] \\
\hline Huperzin & CremophorRH40 & Propylene glycol & $\begin{array}{l}\text { Self-microemusifying } \\
\text { drug delivery system }\end{array}$ & $\begin{array}{l}\text { Enhancing bioavailability and } \\
\text { lymphatic uptake of the drug }\end{array}$ & [79] \\
\hline Curcumin & $\begin{array}{l}\text { Caprylic acid, cremophor } \\
\text { RH 40, cremophor EL }\end{array}$ & Tween 80 and PEG 200 & $\begin{array}{l}\text { Vaginal self-emulsifying } \\
\text { delivery system }\end{array}$ & $\begin{array}{l}\text { Enhancement of drug } \\
\text { penetration }\end{array}$ & {$[80]$} \\
\hline $\begin{array}{l}\text { Cathepsin K } \\
\text { inhibitor (HL235) }\end{array}$ & Capmul MCM EP & $\begin{array}{l}\text { Tween } 20 \text { (surfactant) and } \\
20.0 \% \text { carbitol (cosurfactant) }\end{array}$ & $\begin{array}{l}\text { SEDDS were prepared by } \\
\text { applying D-optimal } \\
\text { mixture design }\end{array}$ & $\begin{array}{l}\text { Improve drug solubility } \\
\text { and drug loading. Increase } \\
\text { bioavailability }\end{array}$ & [81] \\
\hline Ferulic acid & $\begin{array}{l}\text { Glyceryl triacetate, OP-10, } \\
\text { Labrasol combination }\end{array}$ & PEG 400 & $\begin{array}{l}\text { Preparation of } \\
\text { SMEDDS for }\end{array}$ & $\begin{array}{l}\text { Enhancement of oral } \\
\text { solubility of drug with } \\
\text { improved hypnotic activity }\end{array}$ & {$[82]$} \\
\hline $\begin{array}{l}\text { Kaempferol and } \\
\text { quercetin from plant } \\
\text { Moringa oliefera }\end{array}$ & $\begin{array}{l}\text { CrodamolTM P C } \\
\text { (propylene glycol } \\
\text { dicaprylocaprate) }\end{array}$ & $\begin{array}{l}\text { Tween } 80 \text { and polyethylene } \\
\text { glycol } 400\end{array}$ & SMEDDS & $\begin{array}{l}\text { Enhancement of solubility of } \\
\text { the flavonoids }\end{array}$ & [83] \\
\hline Nilotinib & Capryol 90 & Transcutol HP and Tween 80 & SMEDDS & $\begin{array}{l}\text { Enhancement of solubility } \\
\text { of the drug }\end{array}$ & {$[84]$} \\
\hline
\end{tabular}

with a non-volatile solvent, further converted to a solid form by adsorption to a solid carrier. This is a simple and advanced technique to enhance the stability of liquid SEDDS, bypassing its instability in liquid state [66].

Table 3 includes a detailed study of drugs formulated as liquid/solid SMEDDS and their therapeutic outcomes, and Table 4 includes a detailed study of drugs formulated as liquid/solid SNEDDS and their therapeutic outcomes.

\section{Conclusion}

As stated in the literature and with a brief review, it can be now said that SEDDS is a better approach for the formulation and development of delivery systems for low solubility and/or low permeability drugs, to facilitate their dissolution and absorption. The process of manufacturing is excellent and simple and with the use of conventional and commonly available equipments.

Table 4 List of drugs formulated as solid/liquid self-nano emulsified drug delivery systems (SNEDDS)

\begin{tabular}{|c|c|c|c|c|c|}
\hline Drug & Oils & Surfactant/co-surfactant & Formualtion type & Therapeutic outcome & $\overline{\text { Ref. }}$ \\
\hline Naringenin & Triacetin & Tween 80/transcutol P & $\begin{array}{l}\text { Self-nanoemulsifying } \\
\text { drug delivery system }\end{array}$ & Improve oral bioavailability & {$[1]$} \\
\hline Talinolol & $\begin{array}{l}\text { Triacetin, Miglyol } 812, \\
\text { castor oil, isopropyl } \\
\text { myristate, soybean oil, } \\
\text { and olive oil }\end{array}$ & $\begin{array}{l}\text { Span 20, Span 80, Labrafac } \\
\text { PG, Plurol Oleique, and } \\
\text { Lauroglycol 90/ethanol, } \\
\text { PEG 200, PEG 400, } \\
\text { propylene glycol }\end{array}$ & $\begin{array}{l}\text { Self-nanoemulsifying } \\
\text { drug delivery system } \\
\text { (SNEDDS) }\end{array}$ & $\begin{array}{l}\text { Improved permeability } \\
\text { of drug }\end{array}$ & {$[7]$} \\
\hline Glyburide & Miglyol 812, Ethyl oleate & $\begin{array}{l}\text { Tween 80, Cremophore } \\
\text { RH 40/1,2-pranpanediol, } \\
\text { PEG } 400\end{array}$ & $\begin{array}{l}\text { Self-nanoemulsifying } \\
\text { drug delivery system }\end{array}$ & Improved oral bioavailability & {$[20]$} \\
\hline Atazanavir & Maisine 35-1 & Transcutol P and Span 20 & $\begin{array}{l}\text { Self-nanoemulsifying } \\
\text { drug delivery system }\end{array}$ & Enhance oral bioavailability & [29] \\
\hline$\beta$-carotene & Corn oil, orange oil & Tween 80 & $\begin{array}{l}\text { Nanoemulsion-based } \\
\text { delivery systems } \\
\text { formed by spontaneous } \\
\text { emulsification }\end{array}$ & $\begin{array}{l}\beta \text {-carotene bioaccessibility } \\
\text { increased due to greater } \\
\text { solubilization in mixed } \\
\text { micelles }\end{array}$ & [85] \\
\hline Resveratrol & Imwitor & Transcutol, Tween 80 & $\begin{array}{l}\text { Nanoemulsion-based } \\
\text { delivery systems formed by } \\
\text { spontaneous emulsification }\end{array}$ & $\begin{array}{l}\text { Developed a method which } \\
\text { can measure the emulsification } \\
\text { of SEDDS }\end{array}$ & {$[86]$} \\
\hline
\end{tabular}




\section{Abbreviations}

SEDDS: Self-emulsifying drug delivery systems; GIT: Gastrointestinal tract; LFCS: Lipid formulation classification; SMEDDS: Self-microemulsifying drug delivery systems; SNEDDS: Self-nanoemulsifying drug delivery systems; BCS: Biopharmaceutical classification system; LCT: Long chain triglycerides; MCT: Medium chain triglycerides; S-SMEDDS: Solid self-emulsifying drug delivery systems; LMW: Low molecular weight; TPGS: Tocopheryl polyethylene glycol succinate; SLN: Solid lipid Nanoparticles; NLC: Nanostructured lipid carriers; HLB: Hydrophilic lipophilic balance

\section{Acknowledgements}

NA

\section{Authors' contributions}

PB complied and designed the final manuscript data. She collected the basic informations by literature survey and formatted the blinded manuscript as review of self-emulsifying drug delivery systems. AR checked the initially manuscript format and grammatically corrected the blinded manuscript. SV did the final editing of the manuscript. TS contribute in the designing the conclusion part of the manuscript. SB contributed in the designing and final editing of collected manuscript data. He also checked for the plagiarism of the manuscript and edited the final manuscript accordingly. All authors have read and approved the manuscript.

\section{Funding}

NA

\section{Availability of data and materials}

All data and materials are available upon request.

\section{Ethics approval and consent to participate}

NA

\section{Consent for publication}

NA

\section{Competing interests}

The authors declare that they have no competing interests.

\section{Author details}

${ }^{1}$ Columbia Institute of Pharmacy, Vil.-Tekari, Near Vidhan Sabha, Raipur, Chhattisgarh, India. ${ }^{2}$ Pt. Deendayal Upadhyay Smriti Health Science and Aayush University, Raipur, Chhattisgarh, India. ${ }^{3}$ Raipur Institute of Technology, Raipur, Chhattisgarh, India.

\section{Received: 10 January 2020 Accepted: 1 June 2020}

Published online: 10 June 2020

\section{References}

1. Khan AW, Kotta S, Ansari SH, Sharma RK, Ali J (2015) Self-nanoemulsifying drug delivery system (SNEDDS) of the poorly water-soluble grapefruit flavonoid Naringenin: design, characterization, in vitro and in vivo evaluation. Drug Deliv 22:552-561 https://doi.org/10.3109/10717544.2013.878003

2. Morrison PW, Khutoryanskiy W (2015) Theory and practice of supersaturatable formulations for poorly soluble drugs. Ther Deliv 5:12971314 https://doi.org/10.4155/tde.15.92

3. Savjani KT, Gajjar AK, Savjani JK (2012) Drug solubility: importance and enhancement techniques. ISRN Pharm 2012:1-10 https://doi.org/10.5402/ 2012/195727

4. Kavitha K, Ranjani PV (2015) Solubility enhancement - a challenge for hydrophobic drugs. IOSR Journal of Pharmacy and Biological Sciences 10: 50-60 https://doi.org/10.9790/3008-10645060

5. Singh A, Singh V, Rawat G, Juyal D (2015) Self emulsifying systems: a review. Asian J Pharm 9:13 https://doi.org/10.4103/0973-8398.150031

6. Wei Y, Ye X, Shang X, Peng X, Bao Q, Liu M, Guo M, Li F (2012) Enhanced oral bioavailability of silybin by a supersaturatable self-emulsifying drug delivery system ( S-SEDDS). Colloids Surfaces A: Physicochem Eng Asp 396: 22-28 https://doi.org/10.1016/j.colsurfa.2011.12.025

7. Ghai D, Sinha VR (2012) Nanoemulsions as self-emulsified drug delivery carriers for enhanced permeability of the poorly water-soluble selective $\beta 1$ - adrenoreceptor blocker Talinolol. Nanomed Nanotechnol Biol Med 8:618626 https://doi.org/10.1016/j.nano.2011.08.015

8. Leonaviciute G, Bernkop-Schnürch A (2015) Self-emulsifying drug delivery systems in oral (poly)peptide drug delivery. Expert Opin Drug Deliv 12: 1703-1716 https://doi.org/10.1517/17425247.2015.1068287

9. Patel A, Sharma N, Kumar A (2012) Self emulsifying drug delivery system: a gentle approach for drug delivery. Int J Drug Deliv 4:297-309 https://doi. org/10.1098/rstb.2006.1918

10. Nigade PM, Patil SL, Tiwari SS (2012) Self emulsifying drug delivery system (SEDDS): a review. Int J Pharm Bio Sci 2:45-52

11. Rohrer J, Zupančič O, Hetényi G, Kurpiers M, Schnurch AB (2018) Design and evaluation of SEDDS exhibiting high emulsifying properties. J Drug Deliv Sci Technol 44:366-372 https://doi.org/10.1016/j.jddst.2018.01.013

12. Parmar B, Patel U, Bhimani B, Sanghavi K (2012) SMEDDS: A dominant dosage form which improve bioavailability. Am J Pharmtech Res 2:54-72

13. Fei Y, Kostewicz ES, Sheu M, Dressman JB (2013) Analysis of the enhanced oral bioavailability of fenofibrate lipid formulations in fasted humans using an in vitro - in silico - in vivo approach. Eur J Pharm Biopharm 85:12741284 https://doi.org/10.1016/j.ejpb.2013.03.001

14. Choi J, Hyuk N, Kim D, Park J (2019) Comparison of paclitaxel solid dispersion and polymeric micelles for improved oral bioavailability and in vitro anti-cancer effects. Mater Sci Eng C 100:247-259 https://doi.org/10. 1016/j.msec.2019.03.002

15. Gupta S, Kesarla R, Omri A (2013) Formulation strategies to improve the bioavailability of poorly absorbed drugs with special emphasis on self-emulsifying systems. ISRN Pharm 848043:1-16 https://doi.org/10.1155/2013/848043

16. Ding Z, Wang L, Xing Y, Zhao Y, Wang Z, Han J (2019) Enhanced oral bioavailability of celecoxib nanocrystalline solid dispersion based on wet media milling technique: formulation, optimization and in vitro/in vivo evaluation. Pharmaceutics 11:328-345 https://doi.org/10.3390/ pharmaceutics 11070328

17. Tan A, Rao S, Prestidge CA (2013) Transforming lipid-based oral drug delivery systems into solid dosage forms: an overview of solid carriers, physicochemical properties, and biopharmaceutical performance. Pharm Res 30:2993-3017 https://doi.org/10.1007/s11095-013-1107-3

18. Kumar Yadav S, Pharm M, Shrivastava S, Verma S (2014) Applications of self emulsifying drug delivery systems in novel drug delivery-a review. African J Basic Appl Sci 6:6-14 https://doi.org/10.5829/idosi.ajbas.2014.6.1.84248

19. Rokad V, Nagda C, Nagda D (2014) Design and evaluation of solid selfemulsifying drug delivery system of rosuvastatin calcium. J Young Pharm 6: 37-46 https://doi.org/10.5530/jyp.2014.3.7

20. Liu H, Shang K, Liu W, Leng D, Li R, Kong Y, Zhang T (2014) Improved oral bioavailability of glyburide by a self-nanoemulsifying drug delivery system. J Microencapsul 31:277-283 https://doi.org/10.3109/02652048. 2013.843598

21. Sawatdee S, Atipairin A, Yoon AS, Srichana T, Changsan N, Suwandecha T (2019) Formulation development of albendazole-loaded selfmicroemulsifying chewable tablets to enhance dissolution and bioavailability. Pharmaceutics 11:134-153 https://doi.org/10.3390/ pharmaceutics 11030134

22. Kollipara S, Gandhi RK (2014) Pharmacokinetic aspects and in vitro-in vivo correlation potential for lipid-based formulations. Acta Pharm Sin B 4:333349 https://doi.org/10.1016/j.apsb.2014.09.001

23. Mahapatra AK, Murthy PN, Swadeep B, Swain RP (2014) Self-emulsifying drug delivery systems (SEDDS): an update from formulation development to therapeutic strategies. Int J PharmTech Res 6:546-568

24. Khadka P, Ro J, Kim H, Kim I, Kim JT, Kim H, Cho JM, Yun G, Lee J (2014) Pharmaceutical particle technologies: An approach to improve drug solubility, dissolution and bioavailability. Asian J Pharm Sci 9:304-316 https://doi.org/10.1016/j.ajps.2014.05.005

25. Nikolakakis I, Partheniadis I (2017) Self-emulsifying granules and pellets: composition and formation mechanisms for instant or controlled release. Pharmaceutics 9:1-27 https://doi.org/10.3390/pharmaceutics9040050

26. Qi X, Qin J, Ma N, Chou X, Wu Z (2014) Solid self-microemulsifying dispersible tablets of celastrol: formulation development, charaterization and bioavailability evaluation. Int J Pharm 472:40-47 https://doi.org/10. 1016/j.ijpharm.2014.06.019

27. Quan G, Niu B, Singh V, Zhou Y, Wu CY, Pan X, Wu C (2017) Supersaturable solid self-microemulsifying drug delivery system: precipitation inhibition and bioavailability enhancement. Int J Nanomedicine 12:8801-8811 https://doi. org/10.2147/IJN.S149717 
28. Gonçalves A, Nikmaram N, Roohinejad S, Estevinho BN, Rocha F, Greiner R, McClements DJ (2018) Production, properties, and applications of solid selfemulsifying delivery systems (S-SEDS) in the food and pharmaceutical industries. Colloids Surfaces A Physicochem Eng Asp 538:108-126 https:// doi.org/10.1016/j.colsurfa.2017.10.076

29. Singh G, Pai RS (2014) Optimized self-nanoemulsifying drug delivery system of atazanavir with enhanced oral bioavailability: in vitro/in vivo characterization. Expert Opin Drug Deliv 11:1023-1032 https://doi.org/10. $1517 / 17425247.2014 .913566$

30. Zhang Y, Che E, Zhang M, Sun B, Gao J, Han J, Song Y (2014) Increasing the dissolution rate and oral bioavailability of the poorly water-soluble drug valsartan using novel hierarchical porous carbon monoliths. Int J Pharm 473 : 375-383 https://doi.org/10.1016/j.ijpharm.2014.07.024

31. Čerpnjak K, Zvonar A, Vrečer F, Gašperlin M (2015) Development of a solid self-microemulsifying drug delivery system (SMEDDS) for solubility enhancement of naproxen. Drug Dev Ind Pharm 41:1548-1557 https://doi. org/10.3109/03639045.2014.971031

32. Ujhelyi $Z$, Vecsernyés $M$, Fehér $P$, Kosa $D$, Arany $P$, Nemes $D$, Sinka D, Vasvari G, Fenyvesi F, Varadi J, Bacskay I (2018) Physico-chemical characterization of self-emulsifying drug delivery systems. Drug Discov Today Technol 27:81-86 https://doi.org/10.1016/j.ddtec.2018.06.005

33. Rehman FU, Shah KU, Shah SU, Khan IU (2016) From nanoemulsions to selfnanoemulsions, with recent advances in self-nanoemulsifying drug delivery systems (SNEDDS). Expert Opin Drug Deliv 14:1325-1340 https://doi.org/10. 1080/17425247.2016.1218462

34. Baek IH, Ha ES, Yoo JW, Jung Y, Kim MS (2015) Design of a gelatin microparticle-containing self-microemulsifying formulation for enhanced oral bioavailability of dutasteride. Drug Des Devel Ther 9:3231-3238 https:// doi.org/10.2147/DDDT.S86458

35. Lee DH, Yeom DW, Song YS, Cho HR, Choi YS, Kang MJ, Choi YW (2015) Improved oral absorption of dutasteride via Soluplus ${ }^{\oplus}$-based supersaturable self-emulsifying drug delivery system (S-SEDDS). Int J Pharm 478:341-347 https://doi.org/10.1016/j.ijpharm.2014.11.060

36. Petchsomrit A, Sermkaew N, Wiwattanapatapee R (2017) Alginate-based composite sponges as gastroretentive carriers for curcumin-loaded selfmicroemulsifying drug delivery systems. Sci Pharm 85:. https://doi.org/10. 3390/scipharm85010011

37. Savla R, Browne J, Plassat V, Wasan KM, Wasan EK (2017) Review and analysis of FDA approved drugs using lipid-based formulations. Drug Dev Ind Pharm 43:1743-1758 https://doi.org/10.1080/03639045.2017.1342654

38. Rahman MA, Hussain A, Hussain MS, Mirza MA, lqbal Z (2013) Role of excipients in successful development of self-emulsifying/ microemulsifying drug delivery system (SEDDS/SMEDDS). Drug Dev Ind Pharm 39:1-19 https://doi.org/10.3109/03639045.2012.660949

39. Izgelov D, Shmoeli E, Domb AJ, Hoffman A (2020) The effect of medium chain and long chain triglycerides incorporated in self-nano emulsifying drug delivery systems on oral absorption of cannabinoids in rats. Int $J$ Pharm 580:119201 https://doi.org/10.1016/j.jpharm.2020.119201

40. Zaichik S, Steinbring C, Menzel C, Knablb L, Hollerb DO, Ellemunterc $H_{\text {, }}$ Niedermayrc K, Schnurcha AB (2018) Development of self-emulsifying drug delivery systems (SEDDS) for ciprofloxacin with improved mucus permeating properties. Int J Pharm 547:282-290 https://doi.org/10.1016/j. ijpharm.2018.06.005

41. Elfiyani R, Amalia A, Pratama SY (2017) Effect of using the combination of Tween 80 and ethanol on the forming and physical stability of microemulsion of eucalyptus oil as antibacterial. J Young Pharm 9:1-4 https://doi.org/10.5530/jyp.2017

42. Leichner AC, Menzel C, Laf F, Bernkop-schn A (2017) Development and in vitro characterization of a papain loaded mucolytic self-emulsifying drug delivery system (SEDDS). Int J Pharm 530:346-353 https://doi.org/10.1016/j. ijpharm.2017.08.059

43. Bhandari S, Rana V, Tiwary AK (2017) Antimalarial solid self-emulsifying system for oral use: in vitro investigation. Ther Deliv 8:201-213 https://doi. org/10.4155/tde-2016-0092

44. Cheng G, Hu R, Ye L, Wang B, Gui Y, Gao S, Li X, Tang J (2016) Preparation and in vitro/in vivo evaluation of puerarin solid self-microemulsifying drug delivery system by spherical crystallization technique. AAPS PharmSciTech 17:1336-1346 https://doi.org/10.1208/s12249-015-0469-8

45. Milović M, Djuriš J, Djekić L, Vasiljevic D, Ibric S (2012) Characterization and evaluation of solid self-microemulsifying drug delivery systems with porous carriers as systems for improved carbamazepine release. Int J Pharm 436:5865 https://doi.org/10.1016/j.jpharm.2012.06.032

46. Madagul JK, Parakh DR, Kumar RS, Abhang RR (2017) Formulation and evaluation of solid self-microemulsifying drug delivery system of chlorthalidone by spray drying technology. Dry Technol 35:1433-1449 https://doi.org/10.1080/07373937.2016.1201833

47. Ohadi M, Shahravan A, Dehghannoudeh N, Eslaminejad T, Banat IM, Dehghannoudeh G (2020) Potential use of microbial surfactant in microemulsion drug delivery system: a systematic review. Drug Des Devel Ther 14:541-550 https://doi.org/10.2147/DDDT.S232325

48. Kauss T, Gaubert A, Tabaran L, Tonellia G, Phoeunga T, Langloisa MH, White N, Cartwrightd A, Gomese M, Gaudina K (2018) Development of rectal selfemulsifying suspension of a moisture-labile water-soluble drug. Int J Pharm 536:283-291 https://doi.org/10.1016/j.jpharm.2017.11.067

49. Zhao K, Yuan Y, Wang H, Li P, Bao Z, Li Y (2016) Preparation and evaluation of valsartan by a novel semi-solid self-microemulsifying delivery system using Gelucire 44/14. Drug Dev Ind Pharm 42:1545-1552 https://doi.org/10. 3109/03639045.2016.1151034

50. Purohit HS, Wallace C, Giridhar A, Purohit SH, Taylor S, Nagy ZK, Reklaitis GV (2017) Dropwise additive manufacturing of pharmaceutical products for amorphous and self emulsifying drug delivery systems. Int J Pharm 524(1-2): 424-432 https://doi.org/10.1016/j.jpharm.2017.04.003

51. Gao H, Wang M, Sun D, Sun S, Sun C, Liua J, Guanb Q (2017) European journal of pharmaceutical sciences evaluation of the cytotoxicity and intestinal absorption of a self-emulsifying drug delivery system containing sodium taurocholate. Eur J Pharm Sci 106:212-219 https://doi.org/10.1016/j. ejps.2017.06.005

52. Potharaju S, Mutyam SK, Liu M, Green C, Frueh L, Nilsen A, Pou S, Winter R, Riscoe MK, Shankar G (2020) Improving solubility and oral bioavailability of a novel antimalarial prodrug: comparing spray-dried dispersions with selfemulsifying drug delivery systems. Pharm Dev Technol 25:625-639 https:// doi.org/10.1080/10837450.2020.1725893

53. Prüfert F, Fischer F, Leichner C, Zaichik S, Schnürch AB (2020) Development and in vitro evaluation of stearic acid phosphotyrosine amide as new excipient for zeta potential changing self-emulsifying drug delivery systems. Pharm Res 37:1-9 https://doi.org/10.1007/s11095-020-02802-2

54. Lee DR, Kim YH, Park KW, Ho MJ, Jung HJ, Cho HR, Park JS, Choi YS, Yeom DW, Choi YW, Kang MJ (2015) Fujicalin ${ }^{\circledR}$-based solid supersaturable selfemulsifying drug delivery system (S-SEDDS) of tacrolimus for enhanced dissolution rate and oral absorption. J Pharm Investig 45:651-658 https:// doi.org/10.1007/s40005-015-0220-1

55. Sodalee K, Sapsuphan P, Wongsirikul R, Puttipipatkhachorn S (2016) Preparation and evaluation of alpha-mangostin solid self-emulsifying drug delivery system. Asian J Pharm Sci 11:225-226 https://doi.org/10.1016/j.ajps. 2015.11.024

56. Thakare P, Mogal V, Borase P, Dusane J, Kshirsagar S (2016) A review on selfemulsified drug delivery system self-emulsifying. Pharm Biol Eval 3:140-153

57. Yap SP, Yuen KH (2004) Influence of lipolysis and droplet size on tocotrienol absorption from self-emulsifying formulations. Int J Pharm 281:67-78 https://doi.org/10.1016/j.jpharm.2004.05.015

58. Cirri M, Roghi A, Valleri M, Mura P (2016) Development and characterization of fast-dissolving tablet formulations of glyburide based on solid selfmicroemulsifying systems. Eur J Pharm Biopharm 104:19-29 https://doi.org/ 10.1016/j.ejpb.2016.04.008

59. Chatterjee B, Hamed Almurisi S, Ahmed Mahdi Dukhan A, Mandal UK, Sengupta P (2016) Controversies with self-emulsifying drug delivery system from pharmacokinetic point of view. Drug Deliv 23:3639-3652 https://doi. org/10.1080/10717544.2016.1214990

60. Warisnoicharoen W, Lansley AB, Lawrence MJ (2000) Nonionic oil-in-water microemulsions: the effect of oil type on phase behaviour. Int J Pharm 198: 7-27 https://doi.org/10.1016/S0378-5173(99)00406-8

61. Kumpugdee-Vollrath M (2016) Modern characterization techniques for pharmaceutical substances and products. Asian J Pharm Sci 11:14-15 https://doi.org/10.1016/j.ajps.2015.10.011

62. Petchsomrit A, Sermkaew N, Wiwattanapatapee R (2016) Hydroxypropylmethyl cellulose-based sponges loaded self-microemulsifying curcumin: preparation, characterization, and in vivo oral absorption studies. Appl Polym Sci 133:1-10 https://doi.org/10.1002/app.42966

63. Jing B, Wang Z, Yang R, Zheng X, Zhao J, Tang S, He Z (2016) Enhanced oral bioavailability of felodipine by novel solid self-microemulsifying tablets. 
Drug Dev Ind Pharm 42:506-512 https://doi.org/10.3109/03639045.2015. 1058816

64. Guan Q, Zhang G, Sun S, Fan H, Sun C, Zhanga S (2016) Enhanced oral bioavailability of pueraria flavones by a novel solid self-microemulsifying drug delivery system (SMEDDS) dropping pills. Biol Pharm Bull 39:762-769 https://doi.org/10.1248/bpb.b15-00854

65. Anette M (2016) Monoacyl phosphatidylcholine inhibits the formation of lipid multilamellar structures during in vitro lipolysis of self-emulsifying drug delivery systems. Eur J Pharm Sci 108:62-70 https://doi.org/10.1016/j.ejps. 2016.11.022

66. Suram D, Narala A, Veerabrahma K (2020) Development, characterization, comparative pharmacokinetic and pharmacodynamic studies of iloperidone solid SMEDDS and liquisolid compact. Drug Dev Ind Pharm 46(4):587-596 https://doi.org/10.1080/03639045.2020.1742142

67. Deshmukh A, Kulkarni S (2014) Solid self-microemulsifying drug delivery system of ritonavir. Drug Dev Ind Pharm 40:477-487 https://doi.org/10. 3109/03639045.2013.768632

68. Park JB, Choi BK, Kang CY (2015) Effects of absorbent materials on a selfemulsifying drug delivery system for a poorly water soluble drug. J Pharm Investig 45:529-539 https://doi.org/10.1007/s40005-015-0201-4

69. Krstić M, Popović M, Dobričić V, Ibrić S (2015) Influence of solid drug delivery system formulation on poorly water-soluble drug dissolution and permeability. Molecules 20:14684-14698 https://doi.org/10.3390/ molecules200814684

70. Čerpnjak K, Pobirk AZ, Vrečer F, Gašperlin M (2015) Tablets and minitablets prepared from spray-dried SMEDDS containing naproxen. Int J Pharm 495: 336-346 https://doi.org/10.1016/j.jpharm.2015.08.099

71. Czajkowska-Kosnik A, Szekalska M, Amelian A, Szymanska E, Winnicka K (2015) Development and evaluation of liquid and solid self-emulsifying drug delivery systems for atorvastatin. Molecules 20:21010-21022 https://doi.org/ 10.3390/molecules201219745

72. Ishak RAH, Osman R (2015) Lecithin/TPGS-based spray-dried selfmicroemulsifying drug delivery systems: in vitro pulmonary deposition and cytotoxicity. Int J Pharm 485:249-260 https://doi.org/10.1016/j.jpharm.2015. 03.019

73. Chow PY, Gue SZ, Leow SK, Goh LB (2015) Solid self-microemulsifying system (S-SMECS) for enhanced bioavailability and pigmentation of highly lipophilic bioactive carotenoid. Powder Technol 274:199-204 https://doi. org/10.1016/j.powtec.2015.01.020

74. Čerpnjak K, Zvonar A, Vrečer F, Gašperlin M (2015) Characterization of naproxen-loaded solid SMEDDSs prepared by spray drying: the effect of the polysaccharide carrier and naproxen concentration. Int J Pharm 485:215228 https://doi.org/10.1016/j.jpharm.2015.03.015

75. Nanda Kishore R, Yalavarthi PR, Vadlamudi HC, Dhurke R, Kandadi P, Jukanti R, Bandari S (2015) Solid self microemulsification of atorvastatin using hydrophilic carriers: a design. Drug Dev Ind Pharm 41:1213-1222 https://doi. org/10.3109/03639045.2014.938655

76. Sriamornsak $P$, Limmatvapirat $S$, Piriyaprasarth $S$, Mansukmanee $P$, Huang $Z$ (2015) A new self-emulsifying formulation of mefenamic acid with enhanced drug dissolution. Asian J Pharm Sci 10:121-127 https://doi.org/10 1016/j.ajps.2014.10.003

77. Yeom DW, Son HY, Kim JH, Kim SR, Lee SG, Song SH, Chae BR, Choi YW (2016) Development of a solidified self-microemulsifying drug delivery system (S-SMEDDS) for atorvastatin calcium with improved dissolution and bioavailability. Int J Pharm 506:302-311 https://doi.org/10.1016/j.jpharm. 2016.04.059

78. Parakh DR, Patil MP, Dashputre NL, Kshirsagar SJ (2016) Development of self-microemulsifying drug delivery system of mebendazole by spray drying technology: characterization, in vitro and in vivo evaluation. Dry Technol 34: 1023-1042 https://doi.org/10.1080/07373937.2015.1090447

79. Li F, Hu R, Wang B, Gui Y, Cheng G, Gaoa S, Ye L, Tangf J (2017) Selfmicroemulsifying drug delivery system for improving the bioavailability of huperzine A by lymphatic uptake. Acta Pharm Sin B 7:353-360 https://doi. org/10.1016/.j.apsb.2017.02.002

80. Köllner S, Nardin I, Markt R, Griesser J, Prüfert F, Schnürch AB (2017) Selfemulsifying drug delivery systems: design of a novel vaginal delivery system for curcumin. Eur J Pharm Biopharm 115:268-275 https://doi.org/10.1016/j. ejpb.2017.03.012

81. Visetvichaporn V, Kim KH, Jung K, Choc YS, Kim DD (2020) Formulation of self-microemulsifying drug delivery system (SMEDDS) by D-optimal mixture design to enhance the oral bioavailability of a new cathepsin $\mathrm{K}$ inhibitor
(HL235). Int J Pharm 573:118772 https://doi.org/10.1016/j.jpharm.2019. 118772

82. Liu CS, Chen L, Hu YN, Dai JL, Ma B, Tang QF, Tan XM (2020) Selfmicroemulsifying drug delivery system for improved oral delivery and hypnotic efficacy of ferulic acid. Int I Nanomedicine 15:2059-2070 https:// doi.org/10.2147/IJN.S240449

83. Sermkaew N, Plyduang T (2020) Self-microemulsifying drug delivery systems of Moringa oleifera extract for enhanced dissolution of kaempferol and quercetin. Acta Pharma 70:77-88 https://doi.org/10.2478/acph-2020-0012

84. Zakkula A, Gabani BB, Jairam RK, Kiran V, Todma U, Mullangi R (2020) Preparation and optimization of nilotinib self-micro-emulsifying drug delivery systems to enhance oral bioavailability. Drug Dev Ind Pharm 46: 498-504 https://doi.org/10.1080/03639045.2020.1730398

85. Zhang R, Zhang Z, Kumosani T, Khoja S, Abualnaja KO, McClements DJ (2016) Encapsulation of $\beta$-carotene in nanoemulsion-based delivery systems formed by spontaneous emulsification: influence of lipid composition on stability and bioaccessibility. Food Biophys 11:154-164 https://doi.org/10. 1007/s11483-016-9426-7

86. Vasconcelos T, Marques S, Sarmento B (2018) Measuring the emulsification dynamics and stability of self-emulsifying drug delivery systems. Eur J Pharm Biopharm 123:1-8 https://doi.org/10.1016/j.ejpb.2017.11.003

\section{Publisher's Note}

Springer Nature remains neutral with regard to jurisdictional claims in published maps and institutional affiliations.

\section{Submit your manuscript to a SpringerOpen ${ }^{\circ}$ journal and benefit from:}

- Convenient online submission

- Rigorous peer review

- Open access: articles freely available online

- High visibility within the field

- Retaining the copyright to your article

Submit your next manuscript at $\boldsymbol{\nabla}$ springeropen.com 